\title{
Adapting to Teaching and Learning During Covid-19: A Case of Islamic School's Initiative of Self-regulated Learning
}

\author{
Mustajab', Hasan Baharun'2, Zakiyah Fawa'iedah $^{3}$ \\ ${ }^{1}$ IAIN Jember \\ 2,3Universitas Nurul Jadid, Paiton, Probolinggo \\ 1 mustajab.bws@gmail.com \\ 2ha54nbaharun@gmail.com \\ 3fawaidahzakiyah96@gmail.com
}

\section{Article History： Abstract:}

Submitted:

30-09-2020

Accepted:

20-10-2020

Published:

30-12-2020
This study aims to analyze self-regulated learning in Islamic education amid the Covid-19 pandemic. This study incorporates a qualitative approach to understand self-regulated learning at Miftahul Ulum Islamic High School, East Java. The data collection techniques consist of teachers' interviews, teaching and learning observation, and documentation. The results showed that implementing self-regulated learning during the Covid 19 pandemic was carried out online through activities, analysis of learning conditions, determining the learning design, applying strategies, and evaluation. Despite challenges, online self-regulated learning facilitates Miftahul Ulum Islamic School students to participate in learning activities during the Covid-19 Pandemic.

Keywords: Self-regulated Learning, Learning Motivation, Islamic Education. 


\section{Introduction}

The world is currently experiencing a new virus called Coronavirus Diseases 2019 (COVID-19). ${ }^{1}$ The Covid19 virus has had an enormous impact on the social, cultural, religious, economic, and educational sectors. To prevent the transmission of Covid-19, the Indonesian government issued several restrictions, such as prohibition on crowding, social and physical distancing, wearing masks, and always washing hands. ${ }^{2}$ On March 24, 2020, the Ministry of Education and Culture issued an education policy during the Covid-19 Pandemic emergency, in the form of a circular letter explaining the teaching and learning regulation through distance learning. ${ }^{3}$

1 Yuliana, “Corona Virus Diseases (COVID-19); Sebuah Tinjauan Literatur," Wellness And Healthy Magazine 2, no. 1 (2020): 18792.

2 Ali Sadikin and Afreni Hamidah, "Pembelajaran Daring Di Tengah Wabah Covid-19," Biodik: Jurnal Ilmiah Pendidikan Biologi 6, no. 2 (2020): 214-15, doi:10.22437/bio.v6i2.9759.

3 Elya Umi Hanik, "Self Directed Learning Berbasis Literasi
There are various challenges in teaching and learning processes using online tools. This study investigates the teaching and learning processes of Islamic Education (PAI) subject at SMAS Islam Miftahul Ulum Krejengan, Probolinggo.

Islamic education is one of the mandatory lessons expected to contribute to national education goals, namely the formation of devout and virtuous people. Meanwhile, Islamic education learning is a conscious effort made by educators to prepare students to believe, understand, and practice Islamic religious teachings through predetermined guidance, teaching, or training to achieve predetermined goals. ${ }^{4}$ Islamic education learning requires material explanation and

Digital Pada Masa Pandemi Covid19 Di Madrasah Ibtidaiyah," ELEMENTARY: Islamic Teacher Journal 8, no. 1 (2020): 183-208, doi:10.21043/elementary.v8i1.7417.

4 Nur Fadilah, "Peningkatan Prestasi Belajar Pendidikan Agama Islam Melalui Penerapan Card Sort Learning," Nadwa;Jurnal Pendidikan Islam 11, no. 2 (2017): 157-76, doi:10.21580/nw.2017.11.2.1547. 
requires practices such as prayer practice.

Based on the field observation, researchers identify some challenges in the teaching and learning process amid the Covid-19 pandemic at the SMAS Islam Miftahul Ulum (Miftahul Ulum Islamic High School). Many parents complain because they are not familiar with distance learning due to parents' inability to facilitate their children. They also explain that learning activities lack supervision; it is not uncommon for parents to find their children playing games while learning online. Internet availability is also another concern for the family from low economic backgrounds.

Educators at these institutions also find it difficult during distance learning. Educators consider that online learning is less effective because it is not faceto-face. Educators find it challenging to explain Islamic Education learning material in detail and thoroughly. The allocation of short learning time is also an obstacle for educators to provide a deep understanding of students.
Apart from parents and educators, students at SMAS Islam Miftahul Ulum Krejengan, Probolinggo, also experience many challenges in the learning process. In addition to the assignments given almost every day, students also find it challenging to understand learning because of the lack of explanation and guidance from educators, especially in Islamic Education, which requires more practice and examples. Students also often lack focus due to environmental factors that are not supportive, such as the internet factor that often experiences signal interference. These problems make students reluctant to participate in the learning process because of the large number of given tasks.

Ideally, online learning using digital technology should change the way of conveying knowledge and be an alternative to learning carried out in traditional classrooms. ${ }^{5}$ Online learning

5 Mehmet Ali Hamedoğlu, "The Use of Information and Communication Technologies in Classroom Management in Primary Schools," Malaysian Online Journal of 
is learning that is carried out online via internet technologies to support faceto-face learning. The learning process can be done remotely without meeting face-to-face in the room directly, and the learning time is more flexible. ${ }^{6}$ Online learning should also encourage learning to be more active and independent in learning, and learners can learn according to their characteristics and steps. ${ }^{7}$

Educators innovated by designing their learning through self-regulated learning to increase students' learning motivation in Islamic Education learning. In this case, motivation is needed 8

Educational Technology 7, no. 4 (2019): 145-54.

6 Sunday Tunmibi et al., "Impact of E-Learning and Digitalization in Primary and Secondary Schools.," Journal of Education and Practice 6, no. 17 (2015): 53-58.

7 Kesh Rana and Karna Rana, "ICT Integration in Teaching and Learning Activities in Higher Education: A Case Study of Nepal's Teacher Education," Malaysian Online Journal of Educational Technology 8, no. 1 (2020): 36-47, doi:10.17220/mojet.2020.01.003.

8 Amna Emda, "Kedudukan Motivasi Belajar Siswa Dalam Pembelajaran," Lantanida Journal 5, because motivation is one factor that can encourage students to want to learn. ${ }^{9}$ Motivation is defined as a condition that moves individuals to act, 10 act, or behave. ${ }^{11}$ Through motivation, students can develop activities and initiatives and direct and maintain persistence in learning activities. ${ }^{12}$

no. 2 (2018):

172,

doi:10.22373/lj.v5i2.2838,

9 Lori L. Moore, Dustin K. Grabsch, and Craig Rotter, "Using Achievement Motivation Theory to Explain Student Participation in a Residential Leadership Learning Community," Journal of Leadership Education 9, no. 2 (2010): 22-34, doi:10.12806/V9/I2/RF2.

10 Gizem Engin, “An Examination of Primary School Students Academic Achievements and Motivation In Terms of Parents Attitudes, Teacher Motivation, Teacher Self-Efficacy and Leadership Approach," International Journal of Progressive Education 16, no. 1 (2020): 257-76, doi:10.29329/ijpe.2020.228.18.

11 Dewi Juniayanti, Gede Sedanayasa, and I Gede Margunayasa, "Pengaruh Model Pembelajaran Self Regulated Learning Berbantuan Media Lingkungan Terhadap Motivasi Belajar IPA Siswa SD," E-Journal PGSD 4, no. 1 (2016): 1-9.

12 Agus Syakroni, Chusnul Muali, and Hasan Baharun, "Motivation And Learning 
Self-regulated learning originates from Bandura's social cognition theory of interdependent causal structures with three social cognitions:

behavioral, personal, environmental and These three aspects have a cause and effect relationship ${ }^{14}$. When students attempt to self-regulate, performance or behavior will impact the learning environment. ${ }^{15}$ Furthermore, such an environment will trigger the first aspect and continue to the next

Outcomes Through The Internet Of Things; Learning In Pesantren," Journal of Physics: Conference Series 1363 (2019): 1-5, doi:10.1088/17426596/1363/1/012084.

13 Eva Latipah, "Strategi Self Regulated Learning Dan Prestasi Belajar: Kajian Meta Analisis," Jurnal Psikologi 37, no. 1 (2015): 110-29, doi:10.22146/jpsi.7696.

${ }^{14}$ Hafiz Hidayat and Puji Gusri Handayani, "Self Regulated Learning (Study for Students Regular and Training)," Jurnal Penelitian Bimbingan Dan Konseling 3, no. 1 (2018): 50-59, doi:10.30870/jpbk.v3i1.3196.

15 Barry J. Zimmerman, "A Social Cognitive View of SelfRegulated Academic Learning," Journal of Educational Psychology 81, no. 3 (1989): $329-39$, doi:10.1037/0022-0663.81.3.329. element. ${ }^{16}$ This causal relationship repeats the process. 17

Research on self-regulated learning has been carried out by many researchers such as Saputra et al.18, who argue that self-regulated learning had a significant effect on learning achievement. Fasikhah and Fatimah ${ }^{19}$ state that self-regulated learning can improve students'

16 Puri Saraswati, "Self Regulated Learning Strategy, Academic Procrastionation and Academic Achievement," Intuisi 9, no. 3 (2017): 210-23.

17 Ana Kusumaning Wardani and A. Sujadi. A, "Self Regulation Learning Untuk Meningkatkan Motivasi Dan Prestasi Belajar Matematika Siswa Kelas Viia Smp Taman Dewasa Ibu Pawiyatan Yogyakarta Tahun Ajaran 2013/2014," Jurnl Pendidikan Matematika 3, no. 2 (2015): 141-52.

18 Wahyu Nanda Eka Saputra, Irvan Budhi Handaka, and Dita Kurnia Sari, "Self-Regulated Learning Siswa SMK Muhammadiyah Di Kota Yogyakarta: Kedua Orang Tua Berpengaruhkan?," Jurnal Pendidikan (Teori Dan Praktik) 4, no. 1 (2019): 711, doi:10.26740/jp.v4n1.p7-11.

19 Siti Suminarti Fasikhah and Siti Fatimah, "Self-Regulated Learning (SRL) Dalam Meningkatkan Prestasi Akademik Pada Mahasiswa," Jurnal Ilmiah Psikologi Terapan 1, no. 1 (2013): 14555. 
achievement. Lee et al ${ }^{20}$ also said that self-regulated learning strategies are effective in reducing the level of academic procrastination. Mega et al. ${ }^{21}$ state that selfregulated learning and motivation play an important role in academic achievement. El-Adl and Alkharusi 22 explained that self-regulated learning was effective in improving students' independent learning skills.

20 Daeyeoul Lee, Sunnie Lee Watson, and William R. Watson, "The Relationships between SelfEfficacy, Task Value, and SelfRegulated Learning Strategies in Massive Open Online Courses," International Review of Research in Open and Distance Learning 21, no. 1 (2020): $1-22$,

doi:10.19173/irrodl.v20i5.4564.

21 Carolina Mega, Lucia Ronconi, and Rossana De Beni, "What Makes a Good Student? How Emotions, Self-Regulated Learning, and Motivation Contribute to Academic Achievement," Journal of Educational Psychology 106, no. 1 (2014):

121-31, doi:10.1037/a0033546.

22 Adel El-Adl and Hussain Alkharusi, "Relationships between Self-Regulated Learning Strategies, Learning Motivation and Mathematics Achievement," Cypriot Journal of Educational Sciences 15, no. 1 (2020): 104-11, doi:10.18844/cjes.v15i1.4461.
$\mathrm{A}^{\prime}$ yun ${ }^{23}$ argues a significant relationship between selfregulated learning and increased learning motivation, and a good classroom atmosphere.

Likewise, research on motivation in learning includes: Muhammad ${ }^{24}$ said that having high motivation can significantly improve learning outcomes and academic achievement. Tokan and Imakulata25 said that motivation is very influential on behavior and learning achievement. Şahin et al. ${ }^{26}$

23 Qurrotul A'yun, “The Correlation Between Self-Regulated Learning and Motivation To the Achievement of PAI and Budi Pekerti at SMPN 2 Kediri," Didaktika Religia 5, no. 1 (2017): 53-90, doi:10.30762/didaktika.v5i1.853.

24 Maryam Muhammad, "Pengaruh Motivasi Dalam Pembelajaran," Lantanida Journal 4, no. 2 (2017): 87, doi:10.22373/lj.v4i2.1881.

25 Moses Kopong Tokan and Mbing Maria Imakulata, "The Effect of Motivation and Learning Behaviour on Student Achievement," South African Journal of Education 39, no. 1 (2019): 1-8, doi:10.15700/saje.v39n1a1510.

26 Mehmet Şahin, Şule Y. E. Seçer, and Yavuz Erişen, "Perception of 'English' and Motivation in Learning English," Journal of Education and Training 
explained that students who have significantly high motivation always have a high success rate in learning. Adamma et al. ${ }^{27}$ also said that motivation can increase students' academic achievement.

Based on these studies mentioned above, the researchers attempted to integrate the concept of selfregulated learning with learning motivation as a guide for teachers in carrying out their learning activities. In this case, the researcher focused the study on selfregulated learning at Islamic Education SMAS Islam Miftahul Ulum, during the Covid-19 pandemic.

\section{Method}

This research incorporates a qualitative method with the case study approach. The researcher attempted to understand the activities and

Studies 4, no. 9 (2016): 43-60, doi:10.11114/jets.v4i9.1672.

27 Nonye Adamma et al., "Influence of Extrinsic and Intrinsic Motivation on Pupils Academic Performance in Mathematics Onyekwere," SJME (Supremum Journal of Mathematics Education) 2, no. 2 (2018): 52-59, doi:10.1017/CBO9781107415324.004. phenomena in the field to be interpreted as findings. In this case, the researcher describes a systematic, factual, and accurate description of the facts, characteristics, and relationships. ${ }^{28}$

The researcher conducted interviews with school principals, deputy principals, teachers, and students at SMAS Islam Miftahul Ulum, Krejengan, and Probolinggo to get an overview of the implementation of selfregulated learning. Observations were made on online learning activities carried out by teachers and students, the material presented, the methods and media used to stimulate student motivation during the Covid 19 Pandemic.

The data analysis techniques are carried out in stages by referring to Milles and Huberman's concept. The researcher conducted data display then continues with

28 Rijki Ramdani, Munawar Rahmat, and Agus Fakhruddin, "Media Pembelajaran E-Learning Dalam Pembelajaran Pendidikan Agama Islam Di Sma Laboratorium Percontohan Upi Bandung," TARBAWY: Indonesian Journal of Islamic Education 5, no. 1 (2018): 4759, doi:10.17509/t.v5i1.13332. 
data reduction and ends with drawing research conclusions. Checking the validity of the data was carried out by utilizing various sources outside the data for comparison. Researchers used triangulation, namely triangulation of data sources and triangulation of methods.

\section{Result and Discussion}

\section{Result}

The results showed that self-regulated learning facilitates students SMAS Islam Miftahul Ulum, Krejengan, Probolinggo to learn Islamic education subject during the Covid-19 pandemic.

The implementation of selfregulated learning can be described as follows:

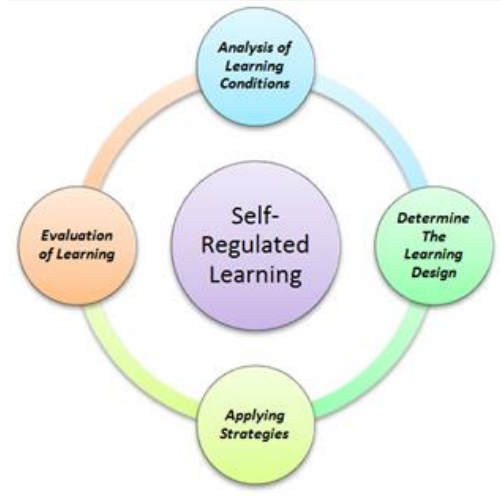

Figure 1: The implementation of Self-regulated learning
Figure 1 describes the selfregulated learning in Islamic Education subject amid Covid-19. The discussion of this section ;

\section{Analysis of Learning Conditions}

Since the learning from a home policy by the Minister of Education and Culture of the Republic of Indonesia on March 24, 2020, SMAS Islam Miftahul Ulum stated and published a letter to the parents and guardian about schooling from home. The teaching and learning processes incorporate online systems such as Zoom, Google Meet, and Whatsapp Groups.

According to Sugiyanto, ${ }^{29}$ online learning carried out by schools raises several different responses for teachers because due to a lack of teachers' experience using digital technologies. Most of senior teachers stated that they have no expertise integrating technologies into learning subjects. Online learning makes learning less

29 Sugianto, Principal of SMAS Islam Miftahul Ulum, Krejengan, Probolinggo, interview on April 01, 2002, 
effective because teachers can only provide material with a little explanation and questions. In contrast to senior teachers, other teachers found little or no problem incorporating technologies into teaching and learning. For instance, Arifin provides learning with several variations, such as creating online modules and creative videos as learning materials.

Many students find it challenging to take part in online learning because they do not have a gadget or cellphone to participate in online learning, so they borrow the tools from a relative or participate in learning together with their friends. Wardani ${ }^{30}$ said that he felt difficult and felt burdened in following the lesson, especially in understanding the teachers' assignments due to technical difficulties such as wifi signal interference.

Starting from the analysis of the learning condition, it can be seen that students at SMAS Islam Miftahul Ulum

30 Wardani, Student of SMAS Islam Miftahul Ulum, Krejengan, Probolinggo, interview on April 08, 2002. are ready to take part in learning. However, not all students have digital technologies. They gather at a particular gathering point such as one of students house who had a good internet connection to keep up with the school's work.

\section{Determine the Learning \\ Design}

Based on the analysis of learning conditions, the teaching and learning process of Islamic religious subjects is carried out by setting learning targets and goals. According to Fauziah, an Islamic Education teacher at SMAS Islam Miftahul Ulum, teachers' self-regulated learning is applied by the school's teachers. At this stage, the teacher sets targets or goals based on the analysis of students' learning conditions at SMAS Islam Miftahul Ulum. These objectives are described in primary competencies, core competencies, and several indicators that students must achieve in Islamic Education learning. The principles of the targets and learning objectives must be measured and evaluated for their success. 
After the learning objectives are determined, the teacher plans the design by utilizing various media and existing learning resources. In this planning design, the teacher also determines how the evaluation technique will be used in Islamic Education learning activities with selfregulated learning.

Through a learning planning design based on analysis of learning conditions, online Islamic education learning at SMAS Islam Miftahul Ulum could run according to teacher expectations. Teachers integrate the scientific learning approach to online learning activities. Online learning designed by teachers at SMAS Islam Miftahul Ulum could create a new learning atmosphere and arouse student learning motivation during the Covid 19 pandemic.

\section{Applying Strategies}

After determining the learning design through the use of various methods, media, and learning resources, the next step is to carry out online-based Islamic education learning planning that has been designed in such a way by the teacher. According to Fauziah ${ }^{31}$, the self-regulated learning strategy is to implement previously designed materials so that learning can be directed and systematic. In this case, the teacher provides Islamic Education learning materials to students to learn and understand themselves and gives students the freedom to seek information through their technology tools as part of their learning resources. The teacher monitors the learning activities through communication via chat What App group. In this monitoring activity, the teacher also motivates students by providing reinforcement and attention, especially for slow learning.

Through these activities, students can monitor their learning to provide further feedback to them. Students become more enthusiastic about participating in online learning through selfregulated learning designs

31 Lilik Fauziah, Teacher of SMAS Islam Miftahul Ulum, Krejengan, Probolinggo, interview on April 12, 2002. 
and understanding the learning materials. Through the freedom given by educators to students to take advantage of various existing learning resources, students also gain new knowledge and experiences in their learning.

\section{Evaluation of Learning}

After carrying out the steps above, the Islamic Education teacher at SMAS Islam Miftahul Ulum conducted an evaluation or learning assessment. It can be seen that the teachers' assessment of Islamic education learning is carried out as follows; the assessment conducted by Islamic Education teachers to determine the learning situation of students and the difficulties they face while participating in online learning. This assessment is carried out by providing questions in the form of descriptions or short answers through the WhatsApp group chat so that educators can capture information briefly.

Next step is the assessment carried out after the educators provide learning material. This assessment is carried out by giving students assignments in the form of questions that have been systematically compiled so that students can work on their pace, concluding that the material that the educators have provided is by the students' understanding, which will then be sent back through the What App class chat group. This assessment is carried out to determine the extent to which students understand the material that has been provided by the educator. Besides, with this assessment, teachers can also change and modify learning to make it more effective in increasing students' competence.

In addition to the assessments above, the presence of students during online learning is also carried out. According to a predetermined time, the activeness of students in commenting during discussions in the what's app group class and the completeness of students' independent assignments is also a consideration for educators in giving grades to online learning. 


\section{Discussion}

Self-regulated learning is a condition in which the learners control their learning activities, monitor, motivate, and manage human resources and objects, and become behavior in the decisionmaking process and the learning process. ${ }^{32}$ A selfregulated learner takes responsibility for learning activities and takes over the autonomy to regulate himself. They can set goals and problems that they might face in achieving their goals, develop perfection standards in attaining goals, and evaluate the best way to achieve their goals. Students who can carry out regulations in learning get better performance than students who do not self-regulate. ${ }^{33}$

Zimmerman $^{34}$ stated that self-regulated learning can be

32 Fasikhah and Fatimah, "SelfRegulated Learning (SRL) Dalam Meningkatkan Prestasi Akademik Pada Mahasiswa."

33 Krishervina Rani Lidiawati, "Peran Pelatihan strategi 'Smart' dalam Meningkatkan Self-Regulated Learning (SRL) Pada Siswa SMP," Jurnal Psikologi Ulayat 3, no. 2 (2020): 158-68, doi:10.24854/jpu51.

34 Zimmerman, "A Social Cognitive View of Self-Regulated Academic Learning." an active participant in metacognition, modification, and behavior in the learning process. Metacognitively, selfregulated learners plan, organize, self-direct, selfmonitor, and self-evaluate at different levels from what they learn. They feel competent and independent. Meanwhile, behaviorally, they choose, arrange, and create their environment for optimal learning. ${ }^{35}$ From this explanation, it can be understood that selfregulated learning is an activity in which students learn actively, arrange, determine their learning goals, monitor, regulate and control cognition, behavioral motivation, and their environment to achieve predetermined learning goals. The characteristics associated with selfregulating learners are similar to those associated with high performance, ${ }^{36}$ high-capacity

35 Abd Mukhid, "Strategi SelfRegulated Learning (Perspektif Teoritik)," Journal of Educational Psychology 82, no. 1 (1998): 33-40.

36 Kajian Meta Analisis, "Strategi Self Regulated Learning Dan Prestasi Belajar: Kajian Meta Analisis," Jurnal Psikologi 37, no. 1 
students, ${ }^{37}$ as opposed to underperformance or learning disabilities. 38

Several researchers suggested several behavioral characteristics of students who have selfregulated learning skills. Students who are selfregulated learners know how to use cognitive strategies, plan, control, direct their metacognition; plan, control time, and have an effort towards completing tasks and creating a pleasant learning environment strong effort and have a discipline. ${ }^{39}$

The regulatory process also has a process grouped into four phases and arranged into four areas: cognitive,

(2015):

doi:10.22146/jpsi.7696.

$110-29$,

37 Fika Widya Pratama, "Peran Self-Regulated Learning Dalam Memoderatori Pembelajaran Dengan Pendekatan Saintifik Terhadap Hasil Belajar Siswa," Satya Widya 33, no. 2 (2017): 99-108, doi:10.24246/j.sw.2017.v33.i2.p99108.

38 Mukhid, "Strategi SelfRegulated Learning (Perspektif Teoritik)."

39 Muhammad Iqbalul Ulum, “Strategi Self-Regulated Learning Untuk Menurunkan Tingkat Prokrastinasi Akademik Siswa," Psympathic: Jurnal Ilmiah Psikologi 3, no. 2 (2016): 153-70, doi:10.15575/psy.v3i2.1107. motivational/affective, behavioral, and contextual. First, the planning phase is as a set of desired goals or specific objectives. Second, the self-monitoring phase is a series of activities that make students aware of the state of cognition, motivation, use of time and effort. Third, the control phase includes the selection and use of mind control strategies, motivation and emotions and control over various academic tasks, and control over the atmosphere and class structure; and fourth, the evaluation phase includes a judgment or decision. 40

Self-regulated learning has a cycle consisting of four stages. First, goal setting, students are encouraged to set their learning goals in advance and what they want to achieve. Students usually set goals based on their previous experiences such as the level of completeness of reading teaching materials, the average of learning time, and the choice of learning environment such as studying with peers so that they can

40 Mukhid, "Strategi SelfRegulated Learning (Perspektif Teoritik)." 
learn at their own pace by setting the learning sequence. Second, applying strategies is a stage where students carry out the learning plan that has been set at the goal-setting stage. Third, monitoring the learning process. Learners realize what they have done, and the strategy's effectiveness depends on whether their performance reaches the goals they have set. Fourth, modifying strategies. Students will evaluate whether the goals they set in this stage set goals according to their learning performance. Besides, they also assess the completion of their objectives. Therefore, they can modify their strategies to better suit their learning performance. ${ }^{41}$

Self-regulation topics were closely associated with motivation. Learners who are motivated to achieve goals will involve self-regulation activities that they believe can

${ }^{41}$ Hui Chun Chu, Yi Meng Liu, and Fan Ray Kuo, "A Mobile SleepManagement Learning System for Improving Students' Sleeping Habits by Integrating a SelfRegulated Learning Strategy: Randomized Controlled Trial," JMIR mHealth and uHealth 6, no. 10 (2018): 1-14, doi:10.2196/11557. help them (e.g., memorizing the material and clarifying information). Instead, selfregulation enhances learning, and competence perceptions are greater for continued motivation and selfregulation to achieve new goals. Theoretically, learners who have self-regulation abilities actively manage aspects of motivation that involve their willingness to learn. ${ }^{42}$

Motivation in learning is one important factor to achieve goals in learning. ${ }^{43}$ Motivation itself is the strength of the circumstances in a person that encourages him to carry out certain activities to achieve a goal. Motivation to learn includes

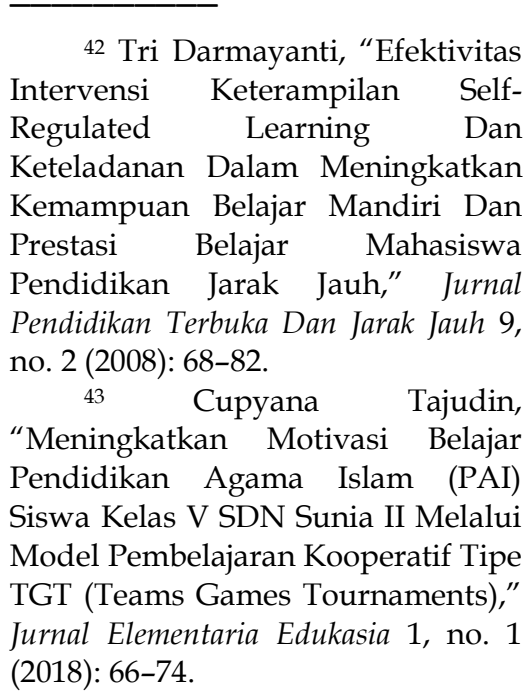

42 Tri Darmayanti, “Efektivitas Intervensi Keterampilan SelfRegulated Learning Dan Keteladanan Dalam Meningkatkan Kemampuan Belajar Mandiri Dan Pendidikan Jarak Jauh," Jurnal Pendidikan Terbuka Dan Jarak Jauh 9, no. 2 (2008): 68-82. Pendidikan Agama Islam (PAI) Siswa Kelas V SDN Sunia II Melalui Model Pembelajaran Kooperatif Tipe TGT (Teams Games Tournaments)," (2018): 66-74. 
the desire to learn, ${ }^{44}$ engaged in learning tasks, and a commitment to continuous learning. ${ }^{45}$ This motivation is essential in the teaching and learning process. Teaching and learning activities will work well if students are diligent in doing assignments, resilient in solving various problems and obstacles. ${ }^{46}$

Several factors influence motivation in learning; first, the influence of family and cultural influences. Second, the role of self-concept. Third, recognition and

44 Nugroho Arif Setiawan, "Pengaruh Pelatihan Penetapan Tujuan (Goal Setting) Untuk Meningkatkan Motivasi Belajar Agama Islam Pada Mahasiswa," AlAdyan 12, no. 1 (2017): 31-51.

45 Azis and Retno Endah Dwi Hastuti, "Hubungan Motivasi Belajar Dengan Prestasi Pendidikan Agama Islam Siswa Sekolah Dasar Muhammadiyah 19 Surakarta," Jurnal Komonikasi Dan Pendidikan Islam 4, no. 1 (2015): 1-40.

46 Syofnidah Ifrianti and Yasyfatara Zasti, "Peningkatan Motivasi Belajar PAI Melalui Metode Pembelajaran Questions Students Have Pada Peserta Didik Kelas IV SDN I Hajimena Kecamatan Natar Kabupaten Lampung Selatan Tahun Pelajaran 2015/2016," Jurnal Pendidikan Dan Pembelajaran Dasar 3, no. I (2016): 123. achievement. $47 \quad$ Motivation also has several important functions in learning, namely: 1) as an incentive to act, 2) as a guide for action, 3) selecting actions. ${ }^{48}$

Meanwhile, self-learning is an activity carried out by a person to gain knowledge, skills, and attitudes that are good and useful for life. ${ }^{49}$ Learning can also be interpreted as a change in individuals' behavior thanks to the interaction between individuals and individuals, interactions between educators and students. 50 One indicator that someone has

47 Azis and Endah Dwi Hastuti, "Hubungan Motivasi Belajar Dengan Prestasi Pendidikan Agama Islam Siswa Sekolah Dasar Muhammadiyah 19 Surakarta."

48 Siti Suprihatin, "Upaya Guru Dalam Meningkatkan Motivasi Belajar Siswa," PROMOSI (Jurnal Pendidikan Ekonomi) 3, no. 1 (2015): 73-82, doi:10.24127/ja.v3i1.144.

49 Fauziah Fauziah, “Hubungan Kecerdasan Emosional Dengan Prestasi Belajar Mahasiswa Semester Ii Bimbingan Konseling UIN Ar-Raniry," Jurnal Ilmiah Edukasi 1, no. 1 (2015): 90-98, doi:10.22373/je.v1i1.320.

50 Ramdani, Rahmat, and Fakhruddin, "Media Pembelajaran E-Learning Dalam Pembelajaran Pendidikan Agama Islam Di Sma Laboratorium Percontohan Upi Bandung." 
learned is a change in behavior in that person, which is caused by a change in either the level of knowledge, skills, or attitudes. Learning is also an activity that creates a relatively permanent change as a result of the efforts made. ${ }^{51}$ By learning, humans make changes so that their behavior develops.

Islamic

Education

learning itself can be understood as a process carried out by educators, parents, and educators about everything related to believing, understanding, living, and practicing the Islamic religion's teachings through guidance, teaching, and/or training activities. ${ }^{52}$ Islamic religious education is

51 Darwin Bangun, "Hubungan Persepsi Siswa Tentang Perhatian Orang Tua, Kelengkapan Fasilitas Belajar, Dan Penggunaan Waktu Belajar Di Rumah Dengan Prestasi Belajar Ekonomi," Jurnal Ekonomi Dan Pendidikan 5, no. 1 (2012): 74-94, doi:10.21831/jep.v5i1.604.

52 Ryan Zeini Rohidin, Rihlah Nur Aulia, and Abdul Fadhil, "Model Pembelajaran PAI Berbasis E-Learning (Studi Kasus Di SMAN 13 Jakarta)," Jurnal Studi Al-Qur'an; Membangun Tradisi Berfikir Qur'ani 11, no. 2 (2015): 114-28, doi:https://doi.org/10.21009/JSQ.0 11.2.02. guidance for a person so that he becomes a maximum Muslim (Kaffah). 53

The general objective of learning Islam is to increase the faith, understanding, appreciation, and practice of students about Islam to become Muslim humans who believe and fear Allah and have noble morals in their personal, social, national, and state life. ${ }^{54}$ Islamic religious education also aims to form pious people, namely people who obey Allah in carrying out worship by emphasizing Muslim personality development, even though moral and ethical subjects do not replace religious subjects. 55

53 Ridhoul Wahidi, "KonsepKonsep Dasar Pendidikan Islam Terpadu," Al-Afkar: Jurnal KeIslaman E Peradaban 3, no. 1 (2016): 70-91, doi:10.28944/afkar.v2i1.89.

54 Setiawan, "Pengaruh Pelatihan Penetapan Tujuan (Goal Setting) Untuk Meningkatkan Motivasi Belajar Agama Islam Pada Mahasiswa."

55 Hamedoğlu, "The Use of Information and Communication Technologies in Classroom Management in Primary Schools." 
Conclusion

Recommendation

Amidst the Covid-19 pandemic Islamic education subject at SMAS Islam Miftahul Ulum is carried out using self-regulated learning. The approach consists of four stages; analysis of learning conditions, determining the learning design, applying learning strategies, and evaluation of learning. Students' motivation to learn Islamic Education increases with using the self-regulated learning model through an online learning system. This can be seen from increasing the learning activeness of student participants through discussions carried out in the Whatsapp group, students' understanding of each material provided by educators, and tasks that students collect according to the specified time.

This result cannot be generalized to all educational institutions, related to increasing student motivation in the pandemic of covid-19 through four steps of selfregulated learning design. However, this research is only specific to one institution, SMAS Islam Miftahul Ulum, which has characteristics and peculiarities in its learning activities. Researchers hope that further research will emerge to investigate selfregulated learning to improve the quality of Islamic education learning in schools.

\section{Bibliography}

A'yun, Qurrotul. "The Correlation Between Self-Regulated Learning and Motivation To the Achievement of PAI and Budi Pekerti at SMPN 2 Kediri." Didaktika Religia 5, no. 1 (2017): 53-90.

doi:10.30762/didaktika.v 5i1.853.

Adamma, Nonye, Onyekwere Pauline Ekwutosim, Okoro Chukwuemeka Unamba, and Eugene. "Influence of Extrinsic and Intrinsic Motivation on Pupils Academic Performance in

Mathematics

Onyekwere." SJME (Supremum Journal of Mathematics Education) 2, no. 2 (2018): 52-59. doi:10.1017/CBO9781107 415324.004 .

Analisis, Kajian Meta. 
"Strategi Self Regulated Learning Dan Prestasi Belajar: Kajian Meta Analisis." Jurnal Psikologi 37, no. 1 (2015): 110-29. doi:10.22146/jpsi.7696.

Azis, and Retno Endah Dwi Hastuti. "Hubungan Motivasi Belajar Dengan Prestasi Pendidikan Agama Islam Siswa Sekolah Dasar

Muhammadiyah 19 Surakarta." Jurnal Komonikasi Dan Pendidikan Islam 4, no. 1 (2015): 1-40.

Bangun, Darwin. "Hubungan Persepsi Siswa Tentang Perhatian Orang Tua, Kelengkapan Fasilitas Belajar, Dan Penggunaan Waktu Belajar Di Rumah Dengan Prestasi Belajar Ekonomi." Jurnal Ekonomi Dan Pendidikan 5, no. 1 (2012): 74-94. doi:10.21831/jep.v5i1.60 4.

Chu, Hui Chun, Yi Meng Liu, and Fan Ray Kuo. "A Mobile SleepManagement Learning System for Improving
Students' Sleeping Habits by Integrating a Self-Regulated Learning Strategy: Randomized Controlled Trial." JMIR mHealth and uHealth 6, no. 10 (2018): 1-14. doi:10.2196/11557.

Cupyana Tajudin. "Meningkatkan Motivasi Belajar Pendidikan Agama Islam (PAI) Siswa Kelas V SDN Sunia II Melalui Model Pembelajaran Kooperatif Tipe TGT (Teams Games Tournaments)." Jurnal Elementaria Edukasia 1, no. 1 (2018): 66-74.

Darmayanti, Tri. "Efektivitas Intervensi Keterampilan Self-Regulated Learning Dan Keteladanan Dalam Meningkatkan

Kemampuan Belajar

Mandiri Dan Prestasi Belajar Mahasiswa Pendidikan Jarak Jauh." Jurnal Pendidikan Terbuka Dan Jarak Jauh 9, no. 2 (2008): 68-82.

El-Adl, Adel, and Hussain Alkharusi.

"Relationships between Self-Regulated Learning Strategies, Learning 
Adapting to Teaching and Learning....

Motivation and

Mathematics

Achievement." Cypriot Journal of Educational Sciences 15 , no. 1 (2020): 104-11.

doi:10.18844/cjes.v15i1.4 461.

Emda, Amna. "Kedudukan Motivasi Belajar Siswa Dalam Pembelajaran." Lantanida Journal 5, no. 2 (2018):

172. doi:10.22373/lj.v5i2.2838.

Engin, Gizem. "An Examination of Primary School Students Academic Achievements and Motivation In Terms of Parents Attitudes, Teacher Motivation, Teacher Self-Efficacy and Leadership Approach." International Journal of Progressive Education 16, no. 1 (2020): 257-76. doi:10.29329/ijpe.2020.22 8.18 .

Fadilah, Nur. "Peningkatan Prestasi Belajar

Pendidikan Agama Islam Melalui Penerapan Card Sort Learning." Nadwa;Jurnal

Pendidikan Islam 11, no. 2 (2017): 157-76. doi:10.21580/nw.2017.11 .2.1547.

Fasikhah, Siti Suminarti, and Siti Fatimah. "SelfRegulated Learning (SRL) Dalam Meningkatkan Prestasi Akademik Pada Mahasiswa." Jurnal Ilmiah Psikologi Terapan 1, no. 1 (2013): 145-55.

Fauziah, Fauziah. "Hubungan Kecerdasan Emosional Dengan Prestasi Belajar Mahasiswa Semester Ii Bimbingan Konseling UIN Ar-Raniry." Jurnal Ilmiah Edukasi 1, no. 1 (2015): 90-98. doi:10.22373/je.v1i1.320.

Hamedoğlu, Mehmet Ali. "The Use of Information and Communication Technologies in Classroom Management in Primary Schools." Malaysian Online Journal of Educational Technology 7, no. 4 (2019): 145-54.

Hanik, Elya Umi. "Self Directed Learning Berbasis Literasi Digital Pada Masa Pandemi Covid-19 Di Madrasah 
Ibtidaiyah."

ELEMENTARY: Islamic

Teacher Journal 8, no. 1 (2020): 183-208. doi:10.21043/elementary .v8i1.7417.

Hidayat, Hafiz, and Puji Gusri Handayani. "Self Regulated Learning (Study for Students Regular and Training)." Jurnal Penelitian Bimbingan Dan Konseling 3, no. 1 (2018): 50-59.

doi:10.30870/jpbk.v3i1.3 196.

Ifrianti, Syofnidah, and Yasyfatara Zasti. “Peningkatan Motivasi Belajar PAI Melalui Metode Pembelajaran Questions Students Have Pada Peserta Didik Kelas IV SDN I Hajimena Kecamatan Natar Kabupaten Lampung Selatan Tahun Pelajaran 2015/2016." Jurnal Pendidikan Dan Pembelajaran Dasar 3, no. I (2016): 1-23.

Juniayanti, Dewi, Gede Sedanayasa, and I Gede Margunayasa.

"Pengaruh Model
Pembelajaran Self

Regulated Learning Berbantuan Media Lingkungan Terhadap Motivasi Belajar IPA Siswa SD." E-Journal PGSD 4, no. 1 (2016): 1-9.

Kilis, Selcan, Ahmet Murat Uzun, and Instructional Technology. "E-Learning in Sports Education Institutions in Turkey." Malaysian Online Journal of Educational Sciences 8, no. 1 (2020): 14-26.

Latipah, Eva. "Strategi Self Regulated Learning Dan Prestasi Belajar: Kajian Meta Analisis." Jurnal Psikologi 37, no. 1 (2015): 110-29.

doi:10.22146/jpsi.7696.

Lee, Daeyeoul, Sunnie Lee Watson, and William R. Watson.

"The

Relationships between Self-Efficacy, Task Value, and Self-Regulated Learning Strategies in Massive Open Online Courses." International Review of Research in Open and Distance 
Adapting to Teaching and Learning....

Learning 21, no. 1 (2020): $1-22$.

doi:10.19173/irrodl.v20i5 .4564 .

Lidiawati, Krishervina Rani.

"Peran Pelatihan strategi

'Smart' dalam

Meningkatkan Self-

Regulated Learning (SRL) Pada Siswa SMP."

Jurnal Psikologi Ulayat

3, no. 2 (2020): 158-68. doi:10.24854/jpu51.

Mega, Carolina, Lucia

Ronconi, and Rossana

De Beni. "What Makes a Good Student? How Emotions, Self-Regulated Learning, and Motivation Contribute to Academic Achievement." Journal of Educational Psychology 106, no. 1 (2014): 121-31. doi:10.1037/a0033546.

Moore, Lori L., Dustin K. Grabsch, and Craig Rotter. "Using

Achievement Motivation Theory to Explain Student Participation in a Residential Leadership Learning Community." Journal of Leadership Education 9, no. 2 (2010): 22-34.

Muhammad, Maryam. "Pengaruh Motivasi Dalam Pembelajaran." Lantanida Journal 4, no. $2 \quad$ (2017): 87. doi:10.22373/lj.v4i2.1881.

Mukhid, Abd. "Strategi SelfRegulated Learning (Perspektif Teoritik)." Journal of Educational Psychology 82, no. 1 (1998): 33-40.

Pratama, Fika Widya. "Peran Self-Regulated Learning Dalam Memoderatori Pembelajaran Dengan Pendekatan Saintifik Terhadap Hasil Belajar Siswa." Satya Widya 33, no. 2 (2017): 99-108. doi:10.24246/j.sw.2017.v 33.i2.p99-108.

Ramdani, Rijki, Munawar Rahmat, and Agus Fakhruddin. "Media Pembelajaran E-Learning Dalam Pembelajaran Pendidikan Agama Islam Di Sma Laboratorium Percontohan Upi Bandung." TARBAWY : Indonesian Journal of 
Mustajab, at all.

Islamic Education 5, no. 1 (2018): 47-59. doi:10.17509/t.v5i1.1333 2.

Rana, Kesh, and Karna Rana. "ICT Integration in Teaching and Learning Activities in Higher Education: A Case Study of Nepal's Teacher Education." Malaysian Online Journal of Educational Technology 8, no. 1 (2020): 36-47. doi:10.17220/mojet.2020. 01.003 .

Rohidin, Ryan Zeini, Rihlah Nur Aulia, and Abdul Fadhil. “Model Pembelajaran PAI Berbasis E-Learning (Studi Kasus Di SMAN 13 Jakarta)." Jurnal Studi Al-Qur'an; Membangun Tradisi Berfikir Qur'ani 11, no. 2 (2015): 114-28. doi:https://doi.org/10.2 1009/JSQ.011.2.02.

Sadikin, Ali, and Afreni Hamidah. "Pembelajaran Daring Di Tengah Wabah Covid-19."

Biodik: Jurnal Ilmiah Pendidikan Biologi 6, no. 2 (2020): 214-15. doi:10.22437/bio.v6i2.97
59.

Şahin, Mehmet, Şule Y. E. Seçer, and Yavuz Erișen. "Perception of 'English' and Motivation in Learning English." Journal of Education and Training Studies 4, no. 9 (2016): 43-60. doi:10.11114/jets.v4i9.16

72.

Saputra, Wahyu Nanda Eka, Irvan Budhi Handaka, and Dita Kurnia Sari. "Self-Regulated Learning Siswa SMK Muhammadiyah Di Kota Yogyakarta: Kedua Orang Tua Berpengaruhkan?" Jurnal Pendidikan (Teori Dan Praktik) 4, no. 1 (2019): 7-11. doi:10.26740/jp.v4n1.p711.

Saraswati, Puri. "Self Regulated Learning Strategy, Academic Procrastionation and Academic Achievement." Intuisi 9, no. 3 (2017): 210-23.

Setiawan, Nugroho Arif. "Pengaruh Pelatihan Penetapan Tujuan (Goal 
Setting)

Untuk

Meningkatkan Motivasi

Belajar Agama Islam

Pada Mahasiswa." Al-

Adyan 12, no. 1 (2017):

31-51.

Suprihatin, Siti. “Upaya Guru

Dalam Meningkatkan

Motivasi Belajar Siswa." PROMOSI

(Jurnal

Pendidikan Ekonomi) 3, no. 1 (2015): 73-82. doi:10.24127/ja.v3i1.144.

Syakroni, Agus, Chusnul Muali, and Hasan Baharun. "Motivation And Learning Outcomes Through The Internet Of Things; Learning In Pesantren." Journal of Physics: Conference Series 1363 (2019): 1-5. doi:10.1088/17426596/1363/1/012084.

Tokan, Moses Kopong, and Mbing Maria Imakulata. "The Effect of Motivation and Learning Behaviour on Student Achievement." South African Journal of Education 39, no. 1 (2019): 1-8. doi:10.15700/saje.v39n1a 1510 .
Tunmibi, Sunday, Ayooluwa Aregbesola, Pascal Adejobi, and Olaniyi Ibrahim. "Impact of ELearning and Digitalization in Primary and Secondary Schools." Journal of Education and Practice 6, no. 17 (2015): 53-58.

Ulum, Muhammad Iqbalul. "Strategi Self-Regulated Learning Untuk Menurunkan Tingkat Prokrastinasi Akademik Siswa." Psympathic: Jurnal Ilmiah Psikologi 3, no. 2 (2016): 153-70. doi:10.15575/psy.v3i2.11 07.

Wahidi, Ridhoul. "KonsepKonsep Dasar Pendidikan Islam Terpadu." Al-Afkar: Jurnal Keislaman \& Peradaban 3, no. 1 (2016): 70-91. doi:10.28944/afkar.v2i1.8 9.

Wardani, Ana Kusumaning, and A. Sujadi. A. "Self Regulation Learning Untuk Meningkatkan Motivasi Dan Prestasi Belajar Matematika Siswa Kelas Viia Smp 
Mustajab, at all.

Taman Dewasa Ibu Pawiyatan Yogyakarta Tahun Ajaran 2013/2014." Jurnl Pendidikan Matematika 3, no. 2 (2015): 141-52.

Yulanda, Novidya.

"Pentingnya Self

Regulated Learning Bagi

Peserta Didik Dalam

Penggunaan Gadget."

Research and

Development Journal of

Education 3, no. 2 (2017):

164-71.

doi:10.30998/rdje.v3i2.20

13.

Yuliana. "Corona Virus

Diseases (COVID-19);

Sebuah Tinjauan

Literatur." Wellness And

Healthy Magazine 2, no.

1 (2020): 187-92.

Zimmerman, Barry J. "A Social Cognitive View of Self-Regulated Academic Learning." Journal of Educational Psychology 81, no. 3 (1989): 329-39. doi:10.1037/00220663.81.3.329. 